\title{
Effect of cobalt supplement on rosemary (rosmarinus officinals $L$ ) A- herb yield, essential oil content and its composition
}

\author{
Nadia Gad *; Abd El-Moez, M-R; Hala Kandil \\ Plant Nutrition Dep. National Research Centre, Dokki, Cairo, Egypt \\ *Corresponding author E-mail: drnadiagad @yahoo.com
}

Copyright $\odot 2014$ Nadia Gad et al. This is an open access article distributed under the Creative Commons Attribution License, which permits unrestricted use, distribution, and reproduction in any medium, provided the original work is properly cited.

\begin{abstract}
Two field experiments were conducted in Research and Production Station, National Research Centre, Nobaria Location, Beheara Governorate, Delta Egypt. Experiments were carried out to study the effect of cobalt concentrations $(0.0,5.0,7.5,10.0,12.5$ and $15.0 \mathrm{ppm})$ on Rosemary herb yield, essential oil content and its composition under drip irrigation system during 2012 and 2013 seasons.

The obtained results indicate that:-

- All cobalt concentrations significantly increased all Rosemary growth and herb yield parameters compared with untreated plants.

- $\quad$ Cobalt at $10 \mathrm{ppm}$ gave the maximum values of fresh herb and its biomass, essential oil and its composition.

- Increasing cobalt levels above $10 \mathrm{ppm}$ in plant growing media cobalt promotive effect reduced.

\section{Introduction}

Rosemary (Rosmarinus officinalis L.), Family Lamiaceae, is an evergreen subshrub with erect or ascending branches, which are bale green and downy when young, later brown and woody. Rosemary is native to the Mediterranean region. It is now widely cultivated for ornamental, culinary, medicinal and perfumery purposes. The leaves and young shoots are used medicinally. The constituents include an essential oil (up to 2\%) with cineole and borneol, camhor and borneol as the main components, plus tannins, saponin and organic acids. These substances give Rosemary a pronounced rubefacient action and dried herb and oil, obtained by steam distillation from fresh parts, are components of antiheumatic liniments and aintments. Rosemary also has sedactive, diuretic, stomachic, cholagogic, tonic, aromatic, antispasmodic and antiseperties. It is especially beneficial for fatigue and neuralgia [1].

Cobalt is beneficial element for plant growth, in higher plants. Cobalt is an essential element for the synthesis of vitamin B12 which is required for human and animal nutrition [2].

Laila Helmy and Nadia Gad [3] reported that cobalt at $25 \mathrm{mg} \mathrm{Kg}-1$ soil significantly increased parsley growth expressed as plant height, leaf fresh and dry weights, and number of leaves per plant as well as root fresh and dry weights. Cobalt fertilization also significantly increased essential oil yield of parsley leaves. The main aroma constituent, 1,3,8-pmenthatriene which forms about $(76 \%)$ of leaves essential oil, showed about (10\%) increase over than of control with $50 \mathrm{mg} \mathrm{Kg}{ }^{-1}$ soil. Eman, Aziz et al [4] stated that cobalt at $15 \mathrm{ppm}$ gave the greatest peppermint fresh and dry weight herb yield, the highest essential oil yield as well as improve the status of macronutrient $(\mathrm{N}, \mathrm{P}$ and $\mathrm{K})$ and micronutrient $(\mathrm{Mn}, \mathrm{Zn}$ and $\mathrm{Cu})$ content. The highest level of cobalt $(30 \mathrm{ppm})$ increased the principal components of menthone $(37.84 \%)$ and isomenthone (15.19\%) and this effect was companied with decreasing the relative content of L-(-)menthol (20.54\%). While cobalt at $20 \mathrm{mg} / \mathrm{Kg}$ soil recorded the highest content of L-(-)- menthol (28.54\%) as compared with other cobalt levels of peppermint essential oil could be successfully produced in newly reclaimed land of Egypt. Eman, Aziz and Nadia Gad [5] showed that all the previous cobalt treatments significantly increased all growth and yield parameters compared with control of lemongrass. Cobalt at $22.5 \mathrm{ppm}$ gave the highest values of fresh and dry herb yields (8.97 and 2.66 ton $^{-1}$ ) as well as recorded the greatest increase in the essential oil yield $\left(63.07 \mathrm{Lh}^{-1}\right)$. While the 
highest cobalt level $(30 \mathrm{ppm})$ increased the principal components of neral $(36.17 \%)$ and geranial $(29.26 \%)$, which represented about $65.43 \%$ of lemongrass oil as well as the quality is generally determined by its content of citral (neral and geranial isomers). This effect was compainied with decreasing the relative content of limonene and citronellol. Nadia Gad and Eman, Aziz [6] demonstrated that cobalt at $22.5 \mathrm{ppm}$ had a significant promotive effect of the lemongrass endogenous hormones (Auxins, Gibberlins and Cytokinens), herbs quality such as total soluble solids, total protein, total lipids, total phenols and the contents of $\mathrm{N}, \mathrm{P}, \mathrm{K}, \mathrm{Mn}, \mathrm{Zn}$ and $\mathrm{Cu}$ as compared with other doses. With increasing cobalt, abscisic acid increased while $\mathrm{Fe}$ decreased. Higher cobalt concentration more than $22.5 \mathrm{ppm}$ decreased the promotive effect. Generally, the obtained results showed that cobalt had a positive role on herbs of lemongrass. Recently, [7] reported that cobalt at 15 ppm gave the highest fresh and dry herb yield (66.20 and 13.19 ton $\mathrm{ha}^{-1}$ ) of Ocimumbalsilicum. Increasing cobalt from 0.0 to 7.5, 15.0 and $22.5 \mathrm{ppm}$ significantly increased the essential oil yield from 38.39 to $94.67,266.76$ and $181,49 \mathrm{~L} \mathrm{ha}^{-1}$. While the highest level of cobalt (30 ppm) recorded $91.15 \mathrm{~L}$ $\mathrm{ha}^{-1}$. The essential oil of Ocimumbasilicum were characterized by high content of linalool (23.43-35.46\%), methyl chavecol (27.68-29.77\%), followed by eugenol (6.76-10.54\%) then 1,8 cineol (2.34-9.65\%) cobalt at 15 ppm increased the principal components of linaloal $(35.46 \%), 1,8$ cineol $(9.65 \%)$, linalyl acetate $(8.71 \%)$ and benzyl acetate $(8.14 \%)$ while cobalt at $30 \mathrm{ppm}$ have possible role in the essential oil compounds and recorded the highest content of methyl chavedol and eugenol. Which were considered the main contributors of the antioxidant activity of volatile extract of sweet basil? Nadia Gad et al [8] stated that applying cobalt at $15 \mathrm{ppm}$ gave a significant increasing in endogenous hormones such as Auxins, Gibberllins, Cytokinens and abscisic acid compared with control. Cobalt at 15 ppm also gave the synergistic effect on chemical constituents as well as nutritional status of sweet basil herbs.

\section{Experimental}

\subsection{Materials and methods}

Two field experiments were conducted in Research and Production Station, National Research Centre, Nobaria Location, Beheara Governorate, Delta Egypt.

\subsection{Soil analysis}

Physical and chemical properties of Nobaria Soil were determined and particle size distributions along with soil moisture were determined as described by Blackmore [9]. Soil pH, EC, cations and anions, organic matter, $\mathrm{CaCO}_{3}$, total nitrogen and available $\mathrm{P}, \mathrm{K}, \mathrm{Fe}, \mathrm{Mn}, \mathrm{Zn}, \mathrm{Cu}$ were run according to Black et al., [10]. Determination of soluble, available and total cobalt was determined according to method described by Cottenie et al., [11]. Some physical and chemical properties of Nubaria soil are shown in Table (1).

Table 1: Some Physical and Chemical Properties of Nobaria Soil

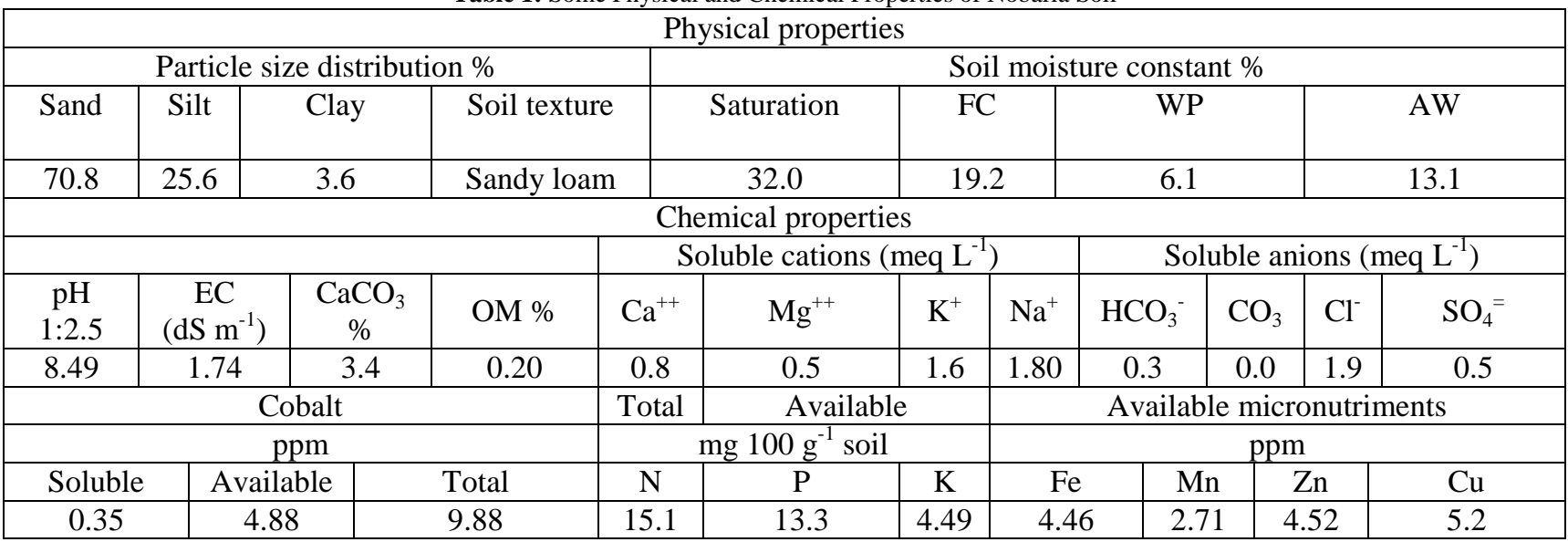

FC (Field capacity), WP (Welting point), AW (Available water).

\subsection{Plant material and experimental work}

Experimental were carried out the effect of cobalt nutrition on Rosemary herb yield quantity and quality. A preliminary pot experiment was conducted at Wire house of National Research Centre during 2011 season to define cobalt concentrations range which gave growth and yield response. Seedlings of Rosemary (at the true leaves) irrigated once with cobalt concentrations: $0.0,5.0,7.5,10.0,12.5,15.0,17.5,20.0,22.5$ and $25.0 \mathrm{ppm}$ according to the preliminary experiment results, the concentrations range of cobalt which gave the Rosemary response 0.0, 5.0, 7.5, 10.0, 12.5 and $15.0 \mathrm{ppm}$. Cobalt at $10 \mathrm{ppm}$ gave the best growth and yield parameters of Rosemary. 
Seeds of Rosemary (Rosmarinus officinals L.) were sown in second week of August during both 2012 and 2013 successive seasons. After one month from sowing, seedlings were irrigated once with cobalt sulphate $(0.0,5.0,7.5$, 10.0, 12.5 and 15.0 ppm Cobalt). Each experiment consisting of 6 treatments. Each treatment represented by three plots. Each plot area was $5 \times 3$ meters consisting of three rows. Twenty five plants in each row $(20 \mathrm{~cm}$ a part $)$ were planted. All the plants received natural agriculture practices whenever they needed. One month after transplanting were harvested $(10 \mathrm{~cm}$ above soil surface), and then plants re-harvested second harvest after one month from first harvest.

\subsection{Measurement of herb growth and yield parameters}

At each harvesting time, all growth and yield parameters as well as fresh and dry weights of herb were recorded according to FAO [12] and Gabal et al [13].

\subsection{Measuring of essential oil}

The essential oil percentage of fresh herb was determined by hydro distillation in Clevenger's apparatus for 3 hours according to A.O.A.S [14]. The essential oil yield (ml plant ${ }^{-1}$ and $\mathrm{L} \mathrm{ha}^{-1}$ ) was calculated.

\subsection{Measuring of essential oil components}

Percentage of fresh herb was determined by hydro-distillation in Clevenger's apparatus for 3 hours according to the Egyptian harvest at monthly intervals. The essential oil yield ( $\mathrm{ml} \mathrm{plant} \mathrm{t}^{-1}$ and $\mathrm{L} \mathrm{ha}^{-1}$ ) was calculated. The resulted oil was dehydrated over anhydrous sodium sulphate in glass vials. The GLC analysis of the oil samples was carried out using HEWIETT PACKARD quipped with FID, HP 6890 Series System, and USA according to Bunzenet al [15].

\subsection{Statistical analysis}

The obtained data were statistically analyzed of variance procedure outlined by SAS [16] computer program and means were compared by LSD method according to Snedecor and Cochran [17].

\section{Results and discussion}

\subsection{Herb yield}

Data presented in Table (2) show that the fresh and dry herb yield of Rosemary ( $\mathrm{g}$ plant ${ }^{-1}$ and ton ha ${ }^{-1}$ ) increased gradually by increasing cobalt levels from 0.0 to $10.0 \mathrm{ppm}$. Cobalt at $10 \mathrm{ppm}$ gave the maximum values of fresh herb and biomass (53.79 and 11.96 ton $\left.\mathrm{ha}^{-1}\right)$. When cobalt addition increased more than $10 \mathrm{ppm}(12.5$ and $15.0 \mathrm{ppm})$ the promotive effect reduced all growth and yield parameters of Rosemary compared with the level of $10 \mathrm{ppm}$ cobalt. These observation are consistent with previous obtained by Nadia Gad et al., [18], who stated that cobalt at 15 ppm resulted the greatest growth and yield of cucumber plants as compared with the higher ones. Eman, Aziz et al [4] added that, low level of cobalt $(7.5 \mathrm{ppm})$ recorded the highest fresh and dry weight of peppermint herb.

\subsection{Essential oil yield}

Data in Table (3), show that, all cobalt doses had a significant promotive effect on the Rosemary essential oil percent and yield (ml plant-1and L ha-1) compared with control. In the first and second cuts, cobalt at 10 ppm recorded the highest values of essential oil percent $(0.21$ and 0.23$)$, content $\left(2.31\right.$ and $\left.2.38 \mathrm{ml} \mathrm{plant}^{-1}\right)$ and yield $\left(122.46 \mathrm{~L} \mathrm{ha}^{-1}\right)$. Increasing cobalt level in Rosemary plant growing media above $10 \mathrm{ppm}$, the promotive effect was reduced. These results are good agreement with those obtained by Liala Helmy and Nadia Gad [3] who found that cobalt at $25 \mathrm{mg} \mathrm{Kg}^{-1}$ soil significantly increased essential oil content in parsley leaves. Nadia Gad et al [19] added that, cobalt is a promising element in the newly reclaimed soils such as Rass Seder, Sinai, Egypt. 
Table 2: Effect of Cobalt on Herb Growth and Yield of Rosemary Her (Mean of Two Seasons).

\begin{tabular}{|c|c|c|c|c|c|c|c|c|c|c|c|c|}
\hline \multirow{3}{*}{$\begin{array}{l}\text { Cobalt } \\
\text { treatment } \\
(\mathrm{ppm})\end{array}$} & \multirow{2}{*}{\multicolumn{2}{|c|}{$\begin{array}{l}\text { Plant hight } \\
\text { (cm) }\end{array}$}} & \multirow{2}{*}{\multicolumn{2}{|c|}{$\begin{array}{l}\text { Branch no. } \\
\text { plant }^{-1}\end{array}$}} & \multicolumn{2}{|c|}{$\begin{array}{c}\text { Herb fresh } \\
\text { weight plant }^{-1}\end{array}$} & \multicolumn{2}{|c|}{$\begin{array}{c}\text { Herb dry } \\
\text { weight plant }^{-1}\end{array}$} & $\begin{array}{c}\text { Total } \\
\text { fresh } \\
\text { weight }\end{array}$ & $\begin{array}{c}\text { Total } \\
\text { dry } \\
\text { weight }\end{array}$ & $\begin{array}{l}\text { Fresh } \\
\text { herb }\end{array}$ & $\begin{array}{l}\text { Dry } \\
\text { herb }\end{array}$ \\
\hline & & & & & & & & & $\begin{array}{c}\text { Per } \\
\text { plant }\end{array}$ & $\begin{array}{c}\text { Per } \\
\text { plant }\end{array}$ & $\begin{array}{l}\text { Ton } \\
\text { fed }^{-1}\end{array}$ & $\begin{array}{l}\text { Ton } \\
\text { fed }^{-1}\end{array}$ \\
\hline & $\begin{array}{l}1^{\text {st }} \\
\text { cut }\end{array}$ & $\begin{array}{l}2^{\text {nd }} \\
\text { cut }\end{array}$ & $\begin{array}{l}1^{\text {st }} \\
\text { cut }\end{array}$ & $\begin{array}{l}2^{\text {nd }} \\
\text { cut }\end{array}$ & $\begin{array}{l}1 \mathrm{st} \\
\text { cut }\end{array}$ & $\begin{array}{l}2^{\text {nd }} \\
\text { cut }\end{array}$ & $\begin{array}{l}1^{\text {st }} \\
\text { cut }\end{array}$ & $\begin{array}{l}2^{\text {nd }} \\
\text { cut }\end{array}$ & \multicolumn{2}{|c|}{ (g) } & $\begin{array}{l}1^{\text {st }} \\
\text { cut }\end{array}$ & $\begin{array}{l}2^{\text {nd }} \\
\text { cut }\end{array}$ \\
\hline Control & 41.11 & 44.19 & 9.44 & 10.15 & 412.33 & 418.40 & 105.11 & 111.2 & 830.73 & 216.13 & 17.95 & 4.62 \\
\hline 5.0 & 52.24 & 56.08 & 12.67 & 13.04 & 720.71 & 726.52 & 182.04 & 188.8 & 1447.23 & 370.82 & 30.26 & 7.93 \\
\hline 7.5 & 58.87 & 62.01 & 15.82 & 16.12 & 1184.01 & 1191.25 & 291.07 & 304.47 & 2375.26 & 595.54 & 46.04 & 11.40 \\
\hline 10.0 & 63.91 & 67.25 & 16.91 & 17.33 & 1222.14 & 1239.97 & 302.26 & 318.92 & 2462.11 & 621.18 & 53.79 & 11.96 \\
\hline 12.5 & 60.43 & 63.14 & 16.04 & 16.94 & 1188.61 & 1216.22 & 294.02 & 311.26 & 2404.83 & 605.28 & 50.42 & 11.56 \\
\hline 15.0 & 56.14 & 58.87 & 15.66 & 16.19 & 1143.02 & 1187.61 & 285.64 & 302.83 & 2330.63 & 588.47 & 48.48 & 11.26 \\
\hline LSD $5 \%$ & 1.55 & 1.12 & 0.16 & 0.07 & 4.6 & 3.62 & 0.95 & 1.64 & 44.63 & 15.70 & 2.0 & 0.30 \\
\hline
\end{tabular}

Table 3: Effect of Cobalt on Essential Oil Content of Rosemary Herb (Mean of Two Seasons).

\begin{tabular}{|c|c|c|c|c|c|c|}
\hline $\begin{array}{c}\text { Cobalt } \\
\begin{array}{c}\text { treatment } \\
(\mathrm{ppm})\end{array}\end{array}$ & \multicolumn{2}{|c|}{$1^{\text {st }}$ cut } & \multicolumn{2}{|c|}{$2^{\text {nd }}$ cut } & $\begin{array}{c}\text { Total } \\
\text { oil yield }\end{array}$ & oil yield \\
\hline & Oil & ml plant & \multicolumn{2}{|c|}{ Oil (\%) } & ml plant & \\
& $(\%)$ & & & ml plant $^{-1}$ & L ha $^{-1}$ \\
\cline { 2 - 6 } Control & 0.12 & 0.73 & 0.13 & 0.74 & 1.47 & 31.70 \\
5.0 & 0.18 & 0.89 & 0.20 & 0.96 & 1.85 & 39.86 \\
7.5 & 0.21 & 1.08 & 0.23 & 1.13 & 2.21 & 58.45 \\
10.0 & 0.26 & 2.31 & 0.27 & 2.38 & 4.69 & 122.46 \\
12.5 & 0.24 & 2.03 & 0.25 & 2.05 & 4.08 & 88.05 \\
15.0 & 0.22 & 1.78 & 0.24 & 1.88 & 3.66 & 78.94 \\
LSD 5\% & 0.3 & 0.16 & 0.20 & 0.17 & 0.42 & 8.16 \\
\hline
\end{tabular}

It`s had a significant positive effect on olive (Manzanello and Arbicon) fruits yield quantity and oil percent especially with organic fertilization. Confirm these results [20] who demonstrated that cobalt at $12.5 \mathrm{ppm}$ gave a beneficial effect of canola oil compared to untreated plants.

\subsection{Essential oil composition}

Data presented in Table (4) obviously reveal that Rosemary oil composition responded greatly to cobalt nutrition, phenylalanine and ornithine at different rate of application. The GLC analysis of essential oil extracted from Rosemary plants which treated with cobalt reveal that 13 peaks were identified, 5 hydrocarbons and 8 oxygenated compounds were detected.

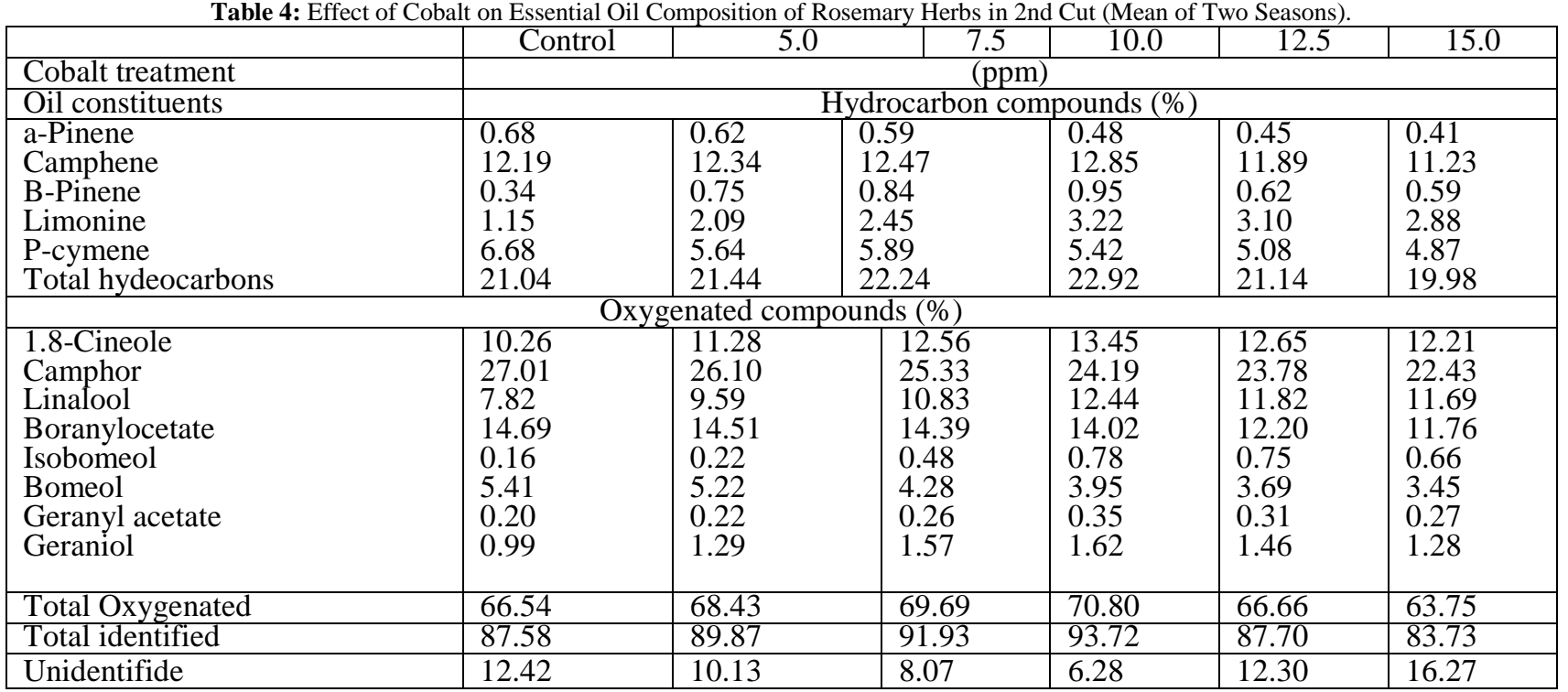


Total hydrocarbons ranged from 19.98 to $22.92 \%$ while total oxygenated compounds ranged from 63.75 to $70.80 \%$. The 1, 8- cineole oil ranged from 10.26 to $13.45 \%$, Camphor (22.43 to 26.10\%), Boranyl acetate (11.76 to $14.69 \%)$ are the major constituents (more than $9 \%$ ) in all cobalt treatments. The higher content of both 1-8- cineole and camphor oils gave the better quality of Rosemary essential oil. In this concern, it is obvious from the obtained results that cobalt at $5 \mathrm{ppm}$ followed by $7.5 \mathrm{ppm}$. Increasing cobalt applications in plant media reduce the promotive effect. These results are in harmony with those obtained by Eman, Aziz et al [4] who found that cobalt at 15 ppm recorded the highest essential oil values of peppermint while the high cobalt levels above $15 \mathrm{ppm}$ reduced the positive effect.

\section{Conclusion}

Cobalt had a significant effect of Rosemary growth, herb yield, herb essential oil yield and its fatty acids components. From this study it could be suggested that cobalt is consider a beneficial element for higher plants. Therefore, considerable attention should be taken concerning applying this element $(\mathrm{Co})$ as a fertilizer, but further studies are needed to learn more about this element and its mechanisms in soil and plant.

\section{References}

[1] Stodola, J. and J. Volak, The illustrated encyclopedia of herbs. Edited by: Sarah Bunney. Chancellor Press, Michelin House, London. (1992) P. 250

[2] Smith, R.M. (1991). Trace elements in human and animal nutrition. Micronut. News. Info. 119.

[3] Laila, M. Helmy and Nadia Gad, Effect of cobalt fertilization on the yield, quality the essential oil composition of parsley leaves. Arab Univ. J. Agric. Sci., Ain Shams Univ., Cairo, 10, 3, (2002), 779-802.

[4] Eman E. Aziz, Nadia Gad and S.M. Khaled, Effect of Cobalt on Growth and Chemical Composition of Peppermint Plant Grown in Newly Reclaimed Soil. Australian J. Basic and Applied Sci.5, 11, (2011), 628-633.

[5] Eman E. Aziz and Nadia Gad, Physiological and Chemical Response of Lemongrass (CymbopogonCitratus L.) to Cobalt Nutrition, A-Herb Yield, Essential Oil Content and Composition. J. Appl. Sci. Research, 7, 11, (2011), 1732-1736.

[6] Nadia Gad and Eman E. Aziz, Physiological and Chemical Response of Lemongrass (Cymbopogon Citratus L.) to Cobalt Nutrition, BEndogenous hormones, chemical and nutritional contents. J. Appl. Sci. Research 7, 12, (2011), 1778-1784.

[7] Eman E. Aziz; Nadia Gad; Lyazzat K. Bekboyeva and Misni Surif, Role of cobalt in sweet Basil (Ocimumbasilicum L.) plants. A- Herb yield, essential oil content and its composition. Middle-East Journal of Scientific Research 14, 1, (2013), 23-28.

[8] Nadia Gad; Eman Aziz; Lyazzat K. Bekbayeva and Misni Surif, Role of cobalt in Sweet Basil (Ocimumbasilicum L.) plants B- Endogenous hormones, Chemical and Nutritional contents. American-Eurasian J. Agric. and Environ. Sci-13, 1, (2013), 16-21.

[9] Blackmore, A.D., T.D. Davis, Jolly and R.H. Walser, Methods of Chemical Analysis of Soils. Newzealand.Soil Dureau. (1972), P A2.1, Dep. No. 10.

[10]Black, C.A.; D.D. Evans; L.E. Ensminger; G.L. White and F.E. Clarck, 'Methods of Soil Analysis', Part 2. Agron. Inc. Madison Wise. (1982).

[11]Cottenei, A. M. Verloo, L. Kiekens, G. Velgh and R. Camerlynck, Chemical Analysis of plants and Soils. (1982), P 44-45. State Univ. Ghent Belgium, 63.

[12]FAO, Soil and plant testing as a basis of fertilizer recommendations. Soil Bull., (1980), 3812.

[13]Gabal, M.R.; I.M. Abd-Allah; F.M. Hass and S. Hassannen, Evaluation of some American tomato cultivars grown for early summer production in Egypt, Annals of Agriculture Science Moshtohor. 22 (1984), 487-500.

[14]A.O.C.S., Official and Tentative Methods of American Oil Chemists Society. 35 East Wacker Drive. Chicago. Illinois, U.S.A. (1982).

[15]BunzenJ. N.; J.Guichard; P. Labble; J. Prevot and J. Trenchant, Partical Manual of Gas Chromatography. (1969), pp. 38-44. J. Trenchant. Ed. EL. Seiviet.Publ. Comp.Amst. London.

[16]SAS, Statistical analysis system, SAS user's guide: statistics. SAS Institute Inc., Edition, Cary, NC. (1996).

[17] Snedecor, G. W. and W. G. Cochran, Statistical methods. $7^{\text {th }}$ Edition Iowa State Univ. Press. Ames. Iowa, USA., (1982).

[18]\ Nadia Gad; A.M. Shafie and M.S. Abdel-Fattah, Effect of cobalt on cucumber growth, fruits yield and mineral composition. J. Agric. Sci. Mansoura Univ., 33, 1, (2008). 909-915.

[19] Nadia Gad, M.R. Abd El-Moez and M. H. El- Sherif, Physiological effect of cobalt on olive yield and fruit quality under Rass Seder conditions. Annals Agric. Sci., Ain Shams Univ., Cairo, 51, 2, (2006), 335-346.

[20] Nadia Gad, Improving quantity and quality of canola oil yield through cobalt nutrition. Agriculture and Biological J. of North America, 1, 5, (2010), 1090-1097. 